\title{
INSIGHTS INTO INTERNATIONAL SERVICE
}

\author{
By JEAN SIO'TIS
}

Brian Urquhart, Hammarskjöld. Knopf, New York, I972, 655 pp., \$12.50. Shirley Hazzard, Defeat of an Ideal: $A$ Study of the Self-Destruction of the United Nations. Atlantic Monthly Press-Little, Brown and Company, Boston, I973, 286 pp., \$8.50.

Henry Cabot Lodge, The Storm Has Many Eyes: A Personal Narrative. W. W. Norton, New York, I973, 272 pp., \$7.50.

Richard Symonds and Michael Carder, The United Nations and the Population Question. McGraw-Hill, New York, I973, 326 pp., \$8.95.

Alexander Szalai, with Margaret Croke and Associates, The United Nations and the News Media. UNITAR, United Nations, New York, I973, 323 pp., $\$ 6.50$ (paper).

$\mathrm{V}$ ARIED experiences and associations with international bureaucracies provide a common element in five recent books related to the United Nations. Two of the books deal principally with crucial issues for the United Nations Secretariat, while the other three emphasize more general aspects of international organization. Taken together, they demonstrate the wide range of contacts and effects deriving from the work of international institutions. The books include excellent biographical and autobiographical material, a treatment of organized approaches to population problems, and a study of news media and the UN.

Brian Urquhart's monumental study of Dag Hammarskjöld probably offers more insights into the structure and functioning of the United Nations than any other work published during the past ten years. Shirley Hazzard has written a passionate and moving account of life in the UN Secretariat during some of its darkest hours. Henry Cabot Lodge's autobiography covers his ambassadorship to the UN, one of the longest held by a representative of the United States. Richard Symonds and Michael Carder record the long battle in the UN family to cancel the taboo on population-control programs. Finally, Alexander Szalai reports the findings of a major research project undertaken by the UN Institute for Training and Research. In some respects the experiences reflected here extend well beyond the UN framework inasmuch as they represent several "typical" categories of international actors. There are those based on technical activities (Symonds and 
Szalai), those of the political arm of international secretariats (Urquhart), those of obscure, enthusiastic service without guiding effect on the organizations being served (Hazzard), and those of the government representatives in daily contact with international secretariats (Lodge).

Brian Urquhart, who has spent the better part of his adult life in the UN, had the exceptional privilege of access to Dag Hammarskjöld's private papers as well as to a great number of other unpublished sources. One wonders, however, whether access to these written sources alone would have enabled him to write such a masterful study of a single man and the politics of his era. For some decades, the catastrophic effect of the telephone on the record available to historians has been beyond doubt. Much of the information and analyses in Urquhart's book were possible only because the author assumed the role of observer-participant and collected information while specific actions were taking place, or was able to interview participants shortly after important events. Obviously, such an opportunity is not given to just any scholar working on the UN. There is reason, therefore, to be particularly grateful to Urquhart for having written so brilliantly and honestly about a man and the institution to which he has always been profoundly attached. Implementing Voltaire's dictum, "On doit des égards aux vivants, on ne doit aux morts que la vérité," is not an easy task, and rare are those writers of friendly biographies who have not fallen victims to hagiography.

The book on Hammarskjöld is a rich source of new information on the United Nations and its most prestigious Secretary General. Although it covers all aspects of Hammarskjöld's action at the head of the organization, some events are stressed more than others, for reasons which are not always clear. I would have been happier had Urquhart devoted more attention to the situation Hammarskjöld found inside the Secretariat and to his actions to remedy that situation. References are made to his conception of his role and of his own responsibility in assuring that the Secretariat did not harbor United States citizens of "subversive" political persuasions, but little is said of the institutionalization of "security clearance" procedures under Hammarskjöld.

As for the descriptions and analyses of the major political initiatives undertaken by Hammarskjöld, they are remarkably well written and documented. Although Urquhart was personally involved in most of them, his narrative is dispassionate and comes close to excellence as an example of political biographical writing. At no point is the reader 
given the impression that Urquhart deliberately chose to highlight those aspects which would enhance the Secretary General's posture as a man of wise political judgment, or to conceal his shortcomings as an administrator whose judgment was not always considered very sound, even by those who admired him. The conclusion one draws from this study is that Hammarskjöld's political acumen in the face of particularly complex situations was generally sharp, but also that he never used his administrative powers to correct major political errors for which some of his senior associates were responsible. His friendship for those in whom he placed his confidence was unfaltering, whatever their mistakes, but this sort of personal loyalty did not always benefit the organization. Urquhart's discussion of the Congo operation provides a case in point: the major blunders committed by some of his subordinates in Leopoldville caused, to a large extent, the failure of Hammarskjöld's attempts early in August 1960 to establish a working relationship with Patrice Lumumba, following the initial skirmishes. The Secretary General's attempts to maintain some form of balance between Congolese parties were seriously and adversely affected by action undertaken in the field late in August and early September. Although "he was taken aback" (p. 445) when he heard of his personal representative's decision to close down all radio stations and airports in Leopoldville, he did not relieve the responsible officer or restrict his operations, as many observers expected. But could he have done so, after having given Andrew Cordier such wide powers a few days earlier?

Urquhart's discussion of Hammarskjöld's institutional leadership confirms, at least implicitly, the point that has often been made by many who worked closely with him or who studied his actions as Secretary General: as one of his subordinates put it privately in the early sixties, Hammarskjöld could be compared to Loyola or Lenin to the extent that, while in office, he developed an institutional ideology which was accepted within the Secretariat and which served as an inspiration to those carrying out his instructions. He failed, however, to establish a structure comparable to the Jesuit Order or the Bolshevik Party, which could have carried on in the same missionary spirit after his death. Hammarskjöld was a man of exceptional intelligence and integrity, but he never really came to grips with crucial organizational problems. A solution for these difficulties could have led to the establishment of a genuine international Secretariat based on the principles which he had espoused so often and so brilliantly. This failure may 
lead us to the conclusion that it is an illusion to expect in one man all the qualities necessary to the attainment of so many and at times contradictory objectives. It is nevertheless the illusion on which the concept of a truly international civil service rests.

Shirley Hazzard's book on the UN Secretariat is not an academic work. Rather, it is an angry and moving testimonial of ideals lost during the course of ten years' service in the UN. It is a well written polemical piece of a kind that is seriously lacking in the literature on the UN. At times, it becomes almost a pamphlet in the original meaning of the term, denouncing those who betrayed the ideals in which Hazzard and thousands of others believed for many years. The author entered UN service when the "big purge" of the McCarthy period was starting. She must have shared many of the frustrations and much of the anguish of thousands of international officials who either faced the inquisition or were powerless witnesses to the degradation of the institutions to which they belonged.

I have believed for a long time that the credibility of the principles on which the UN Secretariat was founded could not be taken seriously as long as those who had a responsibility in acquiescing in the actions of the United States authorities in the early 1950's were still holding key positions in the UN and in associated agencies. As Shirley Hazzard stresses on several occasions, the shock of the purges was all the greater because it was the United States which took the initiative in undermining the very foundations of the Secretariat. It had been accepted as a fact of life in the UN that totalitarian or authoritarian regimes might act in such a fashion, but the two Anglo-Saxon powers had always insisted on the importance of protecting the international Secretariat from undue influences exerted by governments and other sources. Yet it was the United States which demanded and obtained from the Secretary General the right to investigate the political opinions of American staff members and, worst of all, the right to obtain their immediate dismissal. More than twenty years have gone by since the early days of McCarthyism, but the "security clearance" is still in the rule book of the UN, and much of the spirit of the time has survived to this day. Although many of the officials who held responsible positions in the early I950's are either dead or have retired, some of their basic assumptions about the relationship between the Secretariat and the national authorities of the host country still prevail. Until this situation changes, if it ever does, it is very difficult if not impossible to 
ask officials who come from countries which do not share the democratic traditions of the United States to be more loyal to the organization and free from national influences than are their American colleagues.

Notwithstanding the fact that I basically share most of Hazzard's views about what went on in New York, it should be stressed that most of the Secretariat units that were geographically outside the United States, and most of the agencies, were not similarly affected by McCarthyism. The experiences of American officials working under Gunnar Myrdal at the Economic Commission for Europe, as well as many others, were indeed quite different and much more enviable than those of their colleagues in New York. This variation simply demonstrates the validity of one of Hazzard's points. Lack of courage on the part of the UN leadership was largely responsible for the success of the investigators in carrying out their activities. Myrdal never tolerated the slightest interference in his work and in ECE's affairs. Although Roy Cohn, then the right arm of Senator McCarthy, came to Geneva, he did not get very far within the Palais des Nations. UNESCO officials were not as lucky, but their lot was certainly better than that of officials working at UN headquarters.

It would therefore have been useful for Hazzard to have drawn attention to what was going on outside her own place of work. It would indeed be wrong if the reader were left with the impression that all was darkness. That point is particularly important at this stage of the development of the UN, because more and more activities are taking place outside of headquarters. The trend toward decentralization is not altogether alien to the differences of atmosphere and environment between New York and Geneva.

If the ill effects of the purges are to be eradicated, the UN Secretariat and its leadership will certainly have to go through a public denunciation of what was done in the 1950's, or at least through a reasoned analysis of these events. Such an investigation could perhaps help to explain the weakness and absence of moral stamina on the part of those who were supposedly charged with the duty of upholding the principles of an international Secretariat. Hazzard may be judged by some as being too passionate, but in the face of the hypocrisy which characterizes so many pronouncements about the international civil service, such passion is not altogether unjustified. If a balance is to be struck, the UN archives must be allowed to tell the story of why the UN ideals were defeated when they confronted the spirit of inquisition that characterized the McCarthy era. 
Henry Cabot Lodge writes of a diplomatic career that seems largely based on an excellent knowledge of French and hereditary membership in the powers-that-be in the United States after the second World War. His election to the Senate before the war may have been the natural outcome of his upbringing and family tradition, but one would have liked to have his own clarification of the basis of that career and his fifteen years as an American diplomat under both Republican and Democratic administrations. His memoirs do not attempt such a clarification.

His ambassadorship to the United Nations was his longest single period of service, but he devotes to it only thirty-odd pages of his narrative out of almost two hundred describing his adult life. The information and interpretation he gives are certainly interesting, but I cannot help expressing my irritation with the flippancy which characterizes much of what Lodge writes. That may be connected with his class origins, but I think of upper-class New Englanders generally as serious and dedicated people. I do not think one can doubt Lodge's dedication, but his analyses of people and events reflect an attraction for the trivial in public life. It certainly makes for some amusing reading, and Lodge does have a writer's talent; however, I do not find that his memoirs compare favorably with those of other American diplomatists who have written theirs during the past few years.

The book by Richard Symonds and Michael Carder on the United Nations and the population question is basically a historical account, accompanied by critical analyses of attempts to establish international programs in the area of birth control. It covers the League of Nations period briefly and, much more extensively, the United Nations and Specialized Agencies from 1945 to 1970 . Symonds was himself a prominent actor in this field for some time, and he has been in the service of the UN for the better part of its existence. In Ig68, he was appointed by the Secretary General as a consultant to advise on the use of the Trust Fund for Population Activities. His report led to recommendations that the Fund be used to support activities by the Specialized Agencies. Before that time, Symonds had been serving in various capacities under the UN technical assistance programs, and he had had a close exposure to population problems as they were viewed from the vantage point of the developing countries.

In 1932, a League of Nations Assembly document defined birth control as "a practice abhorrent to a large section of religious belief and contrary to the national laws of certain countries." For the most 
part, this view characterized the usual response, until very recently, of UN organs and Specialized Agencies dealing with population problems whenever they received proposals for international action. A coalition of religious forces and policies based on certain Marxist interpretations of population issues consistently blocked a more positive response. The international secretariats were often chided for undertaking studies which, in some views, constituted outrageous interference with moral and religious beliefs.

Symonds and Carder describe the long drawn-out battle to change this policy. They stress the fact that the Secretariat of the UN and some of the Specialized Agencies held a much more positive view toward birth control than did the League Secretariat. During the interwar period, the intergovernmental bodies were leading in this field. Since 1945, however, the roles have been reversed, and it is the international bureaucracies which have been pursuing studies and making recommendations-very often in the face of harsh difficulties. The breakthrough came in the mid-sixties, but it was only in 1969 that the UN really embarked on such programs. Symonds and Carder offer the reader a vivid image of the opposing forces at work, and they discuss in detail the substantive aspects of UN work in this field.

The study by UNITAR on the UN and the news media, under the direction of Alexander Szalai, with Margaret Croke and associates, represents the first large-scale, systematic attempt to analyze relations between the UN and the news media. The volume contains much that is of value, and some of its analyses are undoubtedly interesting. On the whole, however, it falls short of being a satisfactory study, probably because of the constraints under which its authors were working. To some extent, the cause lies in the non-availability of some of the most pertinent data. It is quite clear that the UNITAR research team was in no position to overcome the difficulties arising from the lack of cooperation of certain member countries; it is even more evident that many important points are made in a way which can only be understood by those already familiar with UN machinery.

In spite of these shortcomings, the study does contain most valuable information, particularly if one takes the trouble to interpret some of the collections of data. At the same time, many important questions remain unanswered. One of these relates to the evolution of news coverage of UN affairs since I946. It would seem that the diachronic aspect of the study was left aside because of the absence of serious data reflecting this evolution. It would have been interesting had the authors 
carried out this analysis in relation to at least one or two major newspapers. I am thinking here of the New York Times, whose coverage of the UN has diminished considerably. Would it not have been of value to offer the reader some statistical evidence of this change of emphasis on the part of one of the world's major newspapers? In the case of Le Monde, the proportion of UN news has probably grown over the years. That too would have been interesting to analyze. Another question which remains unanswered refers to the nature of a "UN item." Is it of equal importance to the UN if a given newspaper reports the speech of that particular country's delegate, or a major statement by the Secretary General? If the UN is made up of member states, it also has a voice of its own; it is intellectually disappointing that, in the study, "UN items" were not broken down to distinguish between references to national initiatives within the UN and those relating to actions of the Secretary General or other executive heads. One could list many other shortcomings, but on the whole the book does offer useful material. The collection of data deserves to be completed and analyzed by scholars who may want to answer different sets of questions.

In many respects, all of these works offer insights into the affairs of the UN Secretariat, either by what they do or by what they do not discuss. A case in point is the low profile given to the UN Secretariat in the books by Szalai and Lodge. For example, in the treatment of the 1956 Suez crisis and the establishment of UNEF, Brian Urquhart presents the major decisions as being the result of Hammarskjöld's initiatives, in close cooperation with Lester Pearson and other friendly delegates. On the other hand, Henry Cabot Lodge clearly states (pp. 132ff.) that although Lester Pearson "has rightly been given the lion's share of the credit," the real initiative for the adoption by the General Assembly of a resolution leading to the establishment of the Force was taken in Washington, and that the first draft resolution was probably prepared by Joseph Sisco, who was then handling UN affairs at the State Department.

Lodge describes events leading to the adoption of the resolution in a particularly lively manner when he writes that the choice of the man to present the American draft was left to him and that he "bumped into Mr. Pearson" by sheer chance. "I gave him the text of the resolution and said that the United States Government hoped he would sponsor it. His clear and penetrating mind quickly grasped the significance of the paper and he immediately agreed to sponsor it, with- 
out the usual time-consuming changes of commas here and words there. He seemed to see in a flash, while we were standing there, how much the cause of peace would be helped by his sponsoring a resolution to which the United States was already committed. Due to his perspicacity and leadership a new step was taken in peace-keeping which under ordinary conditions would have taken years of arguing and pettifogging" (pp. 132-33). Urquhart states (p. I76) that even before the emergency meeting of the General Assembly, Pearson had told Hammarskjöld "that he thought a UN Force might become necessary." He also indicates that, as far back as November 1955, "General Burns had discussed with Anthony Nutting, the British Minister of State, the possibility of introducing UN troops between the armed forces of Israel and Egypt." More generally, Urquhart's description of Hammarskjöld as the man who masterminded the UNEF operation is in no way confirmed by Henry Cabot Lodge, and Lodge's casual dismissal of planning finds no support in Urquhart's careful analysis.

As for the situation inside the UN Secretariat during the McCarthyite purges, Lodge makes no reference to his or the United States role in introducing into the United Nations the practices so passionately decried by Shirley Hazzard. Urquhart indicates that Hammarskjöld "wrote to Lodge asking that the remaining UN investigations of American employees be speeded up so that the process could be ended as soon as possible..." (p. 73). On the whole, Urquhart does not devote enough attention to Hammarskjöld's stand on this issue, although the information he offers the reader does confirm the image many of us had of Hammarskjolld: he was certainly not happy with the situation he had inherited but, in opposing the U.S. authorities, he was not prepared to go beyond the payment of indemnities decided upon by the UN Administrative Tribunal.

Another point that deserves to be mentioned relates to the information media. At least three authors (Lodge, Szalai, and Urquhart) deal directly with relations between the UN and the media. It would, however, be very difficult to find a point on which their observations converge. Lodge had an intimate knowledge of American information media before he entered government service. This acquaintance certainly gave him an advantage over other ambassadors who did not have a similar experience, and it undoubtedly helps to explain his lengthy stay in office as a political appointee. Urquhart describes and analyzes the intricate relations between Dag Hammarskjöld and the press. Hammarskjöld was the one Secretary General whose personality appealed to the media, and he was adroit at exploiting that fact. Szalai 
and his colleagues offer us some useful analyses of how the media view the UN, but their book is essentially based on objective data and does not attempt to relate them to any more subjective analyses of the UN's image in the media. It would, for instance, have been interesting if Szalai had been able to go beyond his quantitative data, connecting them with the outcome of certain UN initiatives. More particularly, the image of the Secretary General and the projection of that image still remain to be studied.

None of these books is really "scientific," either from a "traditional" or from a social science point of view. Hazzard, Lodge, and Urquhart have written personal accounts which contain both very valuable information and useful insights. Brian Urquhart's book, in particular, must become standard reading material for all students of the UN and for diplomats, journalists, and politicians interested in the organization. The UNITAR study and the Symonds and Carder book both fall short of being truly scientific-to a large extent because of the close connection of the authors with the subject matter. Richard Symonds, who has been so intimately involved in UN affairs, particularly with population questions, could hardly have been expected to do away with his past before he sat down to write the story of UN action in this area. The UNITAR team was dealing with an even more sensitive subject; it could at no time forget that more than one UN delegate is keeping a careful eye on what is being published by UNITAR. Such close connections may explain the shortcomings of some of the works discussed here, but the successes of these volumes also suggest that a sharper scholarly inquiry of the UN family can still be undertaken. 

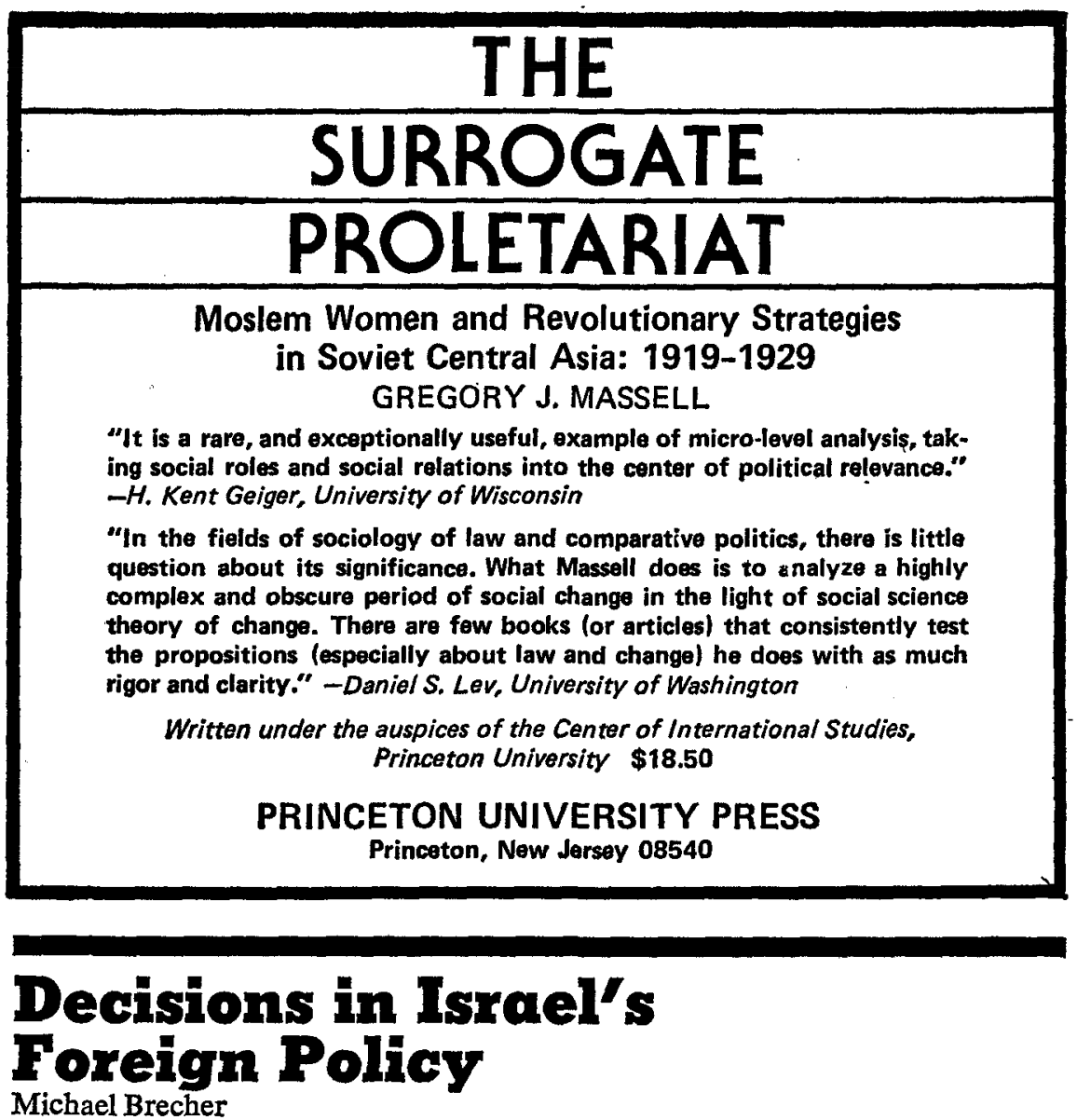

A detailed exploration of seven major cases involving twenty-one strategic and tactical decisions the Israeli government has had to make since independence: Jerusalem, German Reparations, the Korean War and China, the Jordan Waters, the Sinai Campaign, the Six Day War, and the Rogers Proposals. \$25.00

\section{The Thin Blue Line}

International Peacekeeping and Its Future

Indar Jit Rikhye, Michael Harbottle, and Bjørn Egge

As international conflicts continue in the Middle East and in Southeast Asia, and new disputes threaten to erupt around the world, the need for an effective international peacekeeping system is clear. Drawing from their own experiences as leaders of United Nations peacekeeping operations and from the history of international conflict control, both within and outside the United Nations, the authors outline how such a system could be created, structured, and implemented. \$12.50

Yale University Press

New Haven and London 